\title{
In memoriam - Sister Maria Tereza Notarnicola
}

\author{
Magali Hiromi Takashi', Taka Oguisso", Genival Fernandes de Freitas",II \\ ' University of São Paulo, School of Nursing, Postgraduate Program in Nursing Management. São Paulo, Brazil. \\ "University of São Paulo, School of Nursing, Department of Vocational Guidance. São Paulo, Brazil.
}

How to cite this article:

Takashi MH, Oguisso T, Freitas GF. In memoriam - Sister Maria Tereza Notarnicola.

Rev Bras Enferm [Internet]. 2017;70(6):1179-80. DOI: http://dx.doi.org/10.1590/0034-7167.2017700601

Maria Notarnicola, of Italian descent, was born in São Paulo, where she held her primary and secondary studies. She joined the Company of the Daughters of Charity of Saint Vincent de Paul in 1937, when she was almost 17 years old, with the name of Sister Maria Tereza. She worked for five years in Catarina Labouré Day Care Center, in São Paulo, being then transferred to Porto Alegre, where her mother superior considered she was very skillful and could be a nurse. Thus, she was sent to Rio de Janeiro, where she graduated in 1947 by the Luiza de Marillac Nursing School of the Pontifical Catholic University, same year in which she took part in the First National Congress of Nursing held in São Paulo. As a nurse, she served in numerous institutions in Minas Gerais and Rio de Janeiro, in managerial or supervisory functions ${ }^{(1)}$.

In 1958, she was assigned to attend the course in Obstetric Nursing at the School of Nurses of São Paulo Hospital (current Federal University of São Paulo - UNIFESP), when she was a student of Mother Marie Domineuc. Then, she became the director of the Department of Nursing and Supervisor of the Obstetric Clinic of the Clinics Hospital at the School of Medicine of Minas Gerais, remaining in office until 1964, when she was transferred to Rio de Janeiro to participate in the Conferência dos Religiosos do Brasil(2-3).

She received a one-year scholarship (1959/1960) from Maison de France to attend the course of Pedagogy and Didactics applied to Nursing, in Paris ${ }^{(1)}$.

She also actively participated in the Brazilian Association of Nursing (ABEn) at the national level, occupying several positions, such as those of First Treasurer, Coordinator of Permanent and Special Commissions, Manager of Revista Brasileira de Enfermagem, and Executive Secretary in two administrations: those of leda Alencar Barreira and Circe de Melo Ribeiro (second term). At the state level, she worked in Rio de Janeiro and was president of ABEn - Minas Gerais Section ${ }^{(1)}$.

Probably, the most solid and effective contribution of Sister Maria Tereza was in the construction of the ABEn headquarters in Brasília, on a land donated by Companhia Urbanizadora da Nova Capital do Brasil (Novacap), from the Federal Government. The donation was carried out in response to the request of Maria Rosa Sousa Pinheiro, president of ABEn in 1958. In 1967, at the Congress of ABEn, in Brasília, the president Circe de Melo Ribeiro laid the foundation stone of the headquarters as part of the strategy to begin the construction. At the time, the welllocated land was under the threat of being recaptured, because it was in the open, with a lot of red dust, wind, and without any sign of life, which made it hard to find its exact location. In any case, the foundation stone was laid, including the following items in the box: a copy of Correio Braziliense of the opening day of the Congress, the Official Journal of July 20, the record of the donation of the land, a copy of the final deed of the land, the statute of $A B E n$, a picture of the inauguration of the Congress, in addition to the record of the foundation with the signature of those present. Later, it was discovered that, because of a misconception of the surveyor that had identified the site as being of $A B E n$, the stone was laid in the neighbor land, which belonged to a spiritist center ${ }^{(1)}$.

In March 1967, the donation deed was engrossed and signed by the Novacap president and ABEn president, when the Association received a two-month deadline to begin the construction and two years to complete it. Sister Tereza was called to coordinate several campaigns for raising funds to begin the construction. Even so, it was necessary to ask for a deadline extension ${ }^{(1)}$. 
Sister Tereza took full responsibility for the finances of ABEn, chaired at the time by Amália Corrêa de Carvalho, and her performance in the Commission in favor of the headquarters construction was essential for the monitoring and completion of its construction in Brasília. She traveled several times for 18 hours by bus between Rio de Janeiro and Brasília to follow the construction progress in the late 1960s, until its inauguration in 1972 , in the end of her term ${ }^{(2)}$.

She met and collaborated directly with the work of all the ABEn presidents, since the first one, Edith de Magalhães Fraenkel, including Hilda Anna Kirsch, Zaira Cintra Vidal, Marina Bandeira de Oliveira, Waleska Paixão, Glete de Alcântara, Maria Rosa Sousa Pinheiro, Marina de Andrade Resende, Clarice Ferrarini, Circe de Melo Ribeiro, Amália Corrêa de Carvalho, Maria da Graça Corte Imperial, leda Alencar Barreira, and Maria Ivete Ribeiro de Oliveira, until the end of the 1980s. She worked for 33 years in a row for Nursing and for nurses, receiving several honors, such as the Honor Medal in 1964, in Minas Gerais, the Silver Plate in 1967, from ABEn - Guanabara Section, the Diploma of Honor in 1970, and the title of Nurse of the Year in 1971, also from $\mathrm{ABEn}^{(1,3)}$.

It is a very long time. Many Sisters of Charity have excelled in different works for ABEn and for Nursing, but only one devoted herself for so long and in so many activities: Sister Maria Tereza Notarnicola.

\section{REFERENCES}

1. Oguisso T, Freitas GF. Irmã Tereza Notarnicola. Rev Bras Enferm [Internet]. 2006[cited 2017 Jun 29];59(6):7628. Available from: http://www.scielo.br/pdf/reben/v59n6/a08.pdf

2. Oguisso T. Irmã Maria Tereza Notarnicola: uma vida em prol da Enfermagem [Internet]. São Paulo: Portal da Enfermagem; 30 Jun 2011 [cited 2017 Jun 29]. Available from: http://www.portaldaenfermagem.com.br/ plantao_read.asp? $\mathrm{id}=1848$

3. Ferrarini CDT. Homenagem à enfermeira do ano. Rev Bras Enferm. 1972;25(4):31-3. 